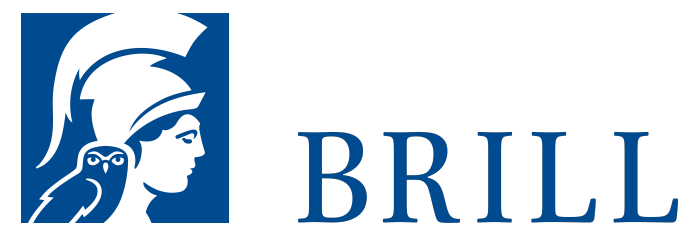

\title{
Western Europe and its Islam
}

Authors:Jan Rath, Rinus Penninx, Kees Groenendijk, and Astrid Meyer

Immigration from North Africa, Asia and elsewhere meant a large influx of Islam into Western Europe. In each country, Muslims organized in various ways and established numerous institutions such as mosques, cemeteries, halâl butchers, schools, broadcasting organizations, and political parties, and slowly but surely the outlines of Muslim communities begun to emerge. The development of those communities is not a matter of Muslims only, but the product of their interaction with the wider environment. The development of the process of institutionalization is the result of their consultations and conflicts with parties involved, particularly with agents from the host society. As Muslim immigrants become ever more a part of Western European societies, the establishment of their institutions both illustrates and affects the processes of sociological, political and legal change that are currently taking place. This book, based on interdisciplinary research, examines the establishment of Muslim institutions in Western Europe, and particularly focuses on the role played by agents from the host society and the political and ideological positions adopted by them in reaction to claims from Muslims.

Readership

The book is of interest to both scholars of cultural anthropology, political science, the sociology of law, the sociology of migration, the sociology of social movements, ethnic studies, religious studies, and urban studies, as well as to practitioners such as politicians, civil servants and ethnic and religious leaders in the field.

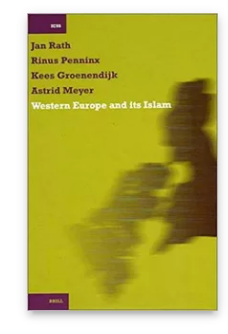

Pages: xii, 308

pp.

Language:

English

Subjects:

Comparative

Social Sciences,

Social Sciences,

Religion \&

Society, Social

Sciences

Publisher: Brill

Series:

International

Comparative

Social Studies,

Volume: 2

E-Book (PDF)

Released online:

22 Nov 2021

ISBN: 978-9O-

04-39785-9

List price

USD $\$ 103.00$

Hardback

Publication date:

12 Sep 2002

ISBN: $978-90-$

04-12192-8

List price

USD $\$ 103.00$ 
Jan Rath (cultural anthropologist) is Associate Professor and Co-Director of the Institute for Migration and Ethnic Studies (IMES) at the University of Amsterdam, the Netherlands.

Rinus Penninx (social scientist) is Professor of Migration and Ethnic Relations and director of the same institute.

Kees Groenendijk (lawyer) is Professor of Sociology of Law in the Institute for Sociology of Law at the Radboud University Nijmegen.

Astrid Meyer (linguist) is a teacher at a Muslim School in Utrecht.

For more information see brill.com

Order information: Order online at brill.com +44330 3330049 | customerservices@brill.com Submission information: brill.com/authors

Titles published by Brill | Fink, Brill | mentis or Brill | Schöningh: +49(o)71 5413279216 | brill@brocom.de 